Article

\title{
Identification of Rice Koji Extract Components that Increase $\beta$-Glucocerebrosidase Levels in Human Epidermal Keratinocytes
}

\author{
Kazuhisa Maeda ${ }^{1,2, *(1)}$, Yuuka Ogino ${ }^{2}$, Ayano Nakamura ${ }^{3}$, Keiji Nakata $^{3}$, Manabu Kitagawa ${ }^{3}$ \\ and Seiki Ito ${ }^{3}$ \\ 1 Bionics Program, Tokyo University of Technology Graduate School, 1404-1 Katakuramachi, Hachioji City, \\ Tokyo 192-0982, Japan \\ 2 School of Bioscience and Biotechnology, Tokyo University of Technology, 1404-1 Katakuramachi, \\ Hachioji City, Tokyo 192-0982, Japan; yk.lax6054@gmail.com \\ 3 MARUKOME Co., Ltd., 883 Amori, Nagano-shi, Nagano 380-0943, Japan; \\ ayano_nakamura@marukome.co.jp (A.N.); keiji_nakata@marukome.co.jp (K.N.); \\ manabu_kitagawa@marukome.co.jp (M.K.); seiki_itou@marukome.co.jp (S.I.) \\ * Correspondence: kmaeda@stf.teu.ac.jp; Tel.: +81-426372442
}

Received: 21 April 2018; Accepted: 15 June 2018; Published: 18 June 2018

\begin{abstract}
Rice miso contains many ingredients derived from rice koji and has been a valuable source of nutrition since ancient times. We found that the consumption of rice miso led to improvements in the moisture content of cheek stratum corneum, skin viscoelasticity, and skin texture. Further, rice miso extract was found to increase the mRNA expression and activity of $\beta$-glucocerebrosidase ( $\beta$-GCase), an enzyme involved in ceramide synthesis in the stratum corneum, in cultures. In this study, we identified the lipid-derived components of rice koji that increase the $\beta$-GCase activity in cultured human epidermal keratinocytes. The methanol fraction of rice koji extract induced an increase in the mRNA expression and activity of $\beta$-GCase in keratinocytes. The active fraction of rice koji was found to contain phosphatidic acid (PA) and lysophosphatidic acid (LPA). The total PA concentration in rice $k o j i$ was $973.9 \mathrm{ng} / \mathrm{mg}$ dry weight, which was 17.5 times higher than that in steamed rice. Among the molecular species, PA_18:2/18:2 was the most frequently found. The total LPA concentration in rice koji was $29.6 \mathrm{ng} / \mathrm{mg}$ dry weight, and 2-LPA_18:2 was the most frequently found LPA. Since PA and LPA increase the mRNA expression and activity of $\beta$-GCase in keratinocytes, they are thought to be the active ingredients in rice koji that increase the $\beta$-GCase levels in human epidermal keratinocytes.
\end{abstract}

Keywords: Aspergillus oryzae; rice koji; phosphatidic acid; lysophosphatidic acid; $\beta$-glucocerebrosidase

\section{Introduction}

Rice koji, which is a solid-state culture of koji molds (Aspergilus oryzae) in rice, is used as a raw material for rice miso. Rice miso contains many ingredients derived from rice koji and has been a valuable source of nutrition since ancient times. We found that ingesting rice miso improved the moisture content in cheek stratum corneum, skin viscoelasticity, and texture [1]. Furthermore, the effect of miso extract on ceramide synthesis in epidermal keratinocytes was examined in cultured cells, and the mRNA expression and activity of glucocerebrosidase ( $\beta$-GCase) in these cells increased when the cells were treated with miso extract [1]. From these results, it was hypothesized that the moisture level of the skin improves by everyday consumption of miso soup made from rice miso and that this may occur via increasing the ceramide content of the stratum corneum [1]. A. oryzae produces and secretes many types of enzymes, including $\alpha$-amylase, which degrades starch; glucoamylase; 
transglucosidase; acid protease, which degrades protein; and acidic carboxypeptidase [2,3], as it grows. In addition, rice koji contains various nutrients and supplies the necessary nutrients for yeast and lactic acid bacteria. These nutrients are especially rich in vitamins of the $\mathrm{B}$ group and include molybdenum; biotin; vitamins B1, B2, and B6; folic acid; pantothenic acid; and niacin [4]. Furthermore, mono- and diacylglycerol are converted to free fatty acids by the lipid-decomposing enzymes of rice $k o j i$ [5], and other studies have suggested that the free fatty acid content in miso contributes to its antimutagenic activities [6]. The main constituent fatty acids of $A$. oryzae are lignoceric acid and, particularly, 2-oxy lignoceric acid and 2,3-dioxyl lignoceric acid, with phytosphingosine reported as the major long-chain constituent [7]. Rice bran malt contains a bifidobacterial growth-promoting substance and glucosylceramide, which improve intestinal bacterial flora in mice [8,9]. It has also been reported that $A$. oryzae exhibits antioxidant activity [10] and produces multiple cathepsin B-inhibiting components [11]. Rice koji is used for most Japanese fermented foods, including miso, soy sauce, amazake, Japanese sake, and malt vinegar. Rice koji and sake lees have also been used as cosmetics and skin moisturizing agents for many years. In this paper, we report on the lipid-derived components of rice koji that increase $\beta$-GCase levels in cultured human epidermal keratinocytes.

\section{Materials and Methods}

\subsection{Materials}

Human epidermal keratinocytes used for a three-dimensional epidermis model were purchased from the Japan Tissue Engineering Co. Ltd. (Tokyo, Japan). Rice koji, which is a solid-state culture of koji molds (A. oryzae) in rice, was obtained from Marukome Co., Ltd. (Nagano, Japan). Reagents not described in the text were obtained from Wako Pure Chemical Industries, Ltd. (Osaka, Japan).

\subsection{Preparation of Rice Koji Extract}

Five hundred grams of fermented rice koji produced by an A. oryzae addition to steamed rice was extracted using $3 \mathrm{~L}$ of chloroform/methanol (2:1). The extract was filtered and concentrated under reduced pressure on a rotary evaporator. The concentrated extract was fractionated sequentially with $3 \mathrm{~L}$ of chloroform, $3 \mathrm{~L}$ of acetone, and $3 \mathrm{~L}$ of methanol using a silica gel column $(5 \mathrm{~cm} \times 35 \mathrm{~cm})$, and the fractionated solution was recovered. After concentrating this solution under reduced pressure with an evaporator, the weight of the sample was measured, and each sample was adjusted to a $5 \mathrm{mg} / \mathrm{mL}$ concentration by the addition of ethanol.

\subsection{Effects of Fractions of Rice Koji Extracts on Cell Proliferation and $\beta$-GCase Activity in Cultured Human Keratinocytes}

Human epidermal keratinocytes were seeded in a 96-well plate at a density of $1 \times 10^{4}$ cells/well, cultured in Dulbecco's modified Eagle's medium containing $10 \%$ fetal bovine serum (FBS-DMEM) for $24 \mathrm{~h}$ and exchanged into $99 \mu \mathrm{L}$ of $2 \%$ FBS-DMEM. Subsequently, $1 \mu \mathrm{L}$ each of the chloroform fraction, acetone fraction, and methanol fraction of the chloroform/methanol (2:1) extract of rice koji was added $(n=4)$. Then, the cells were cultured in a $\mathrm{CO}_{2}$ incubator for three days. After culturing, $10 \mu \mathrm{L}$ of Cell Counting Kit-8 solution (Dojindo Laboratories, Inc., Kumamoto, Japan) was added to each well, and after $2 \mathrm{~h}$, the absorbance (at $450 \mathrm{~nm}$ ) was measured with a microplate reader (Multi-Detection Microplate Powerscan HT; BioTek, Winooski, VT, USA) to obtain the number of cells. In this method, the tetrazolium salt WST-8 (2-(2-methoxy-4-nitrophenyl)-3-(4-nitrophenyl)-5-(2,4-disulfophenyl)-2H-tetrazolium, monosodium salt) is reduced by intracellular dehydrogenases, and the absorbance at $450 \mathrm{~nm}$ of the generated water-soluble formazan is measured to determine the number of living cells. The number of cells and the amount of formazan produced are linearly proportional.

$\beta$-GCase activity was determined using 4-methylumbelliferyl $\beta$-D-glucopyranoside [1]. Human keratinocytes cultured for three days in the 96-well plate were washed twice with PBS, and 
$30 \mu \mathrm{L}$ of $0.01 \mathrm{~mol} / \mathrm{L}$ acetate buffer $(\mathrm{pH}=5.0)$ and $40 \mu \mathrm{L}$ of a $5 \mathrm{mmol} / \mathrm{L} 4$-methylumbelliferyl $\beta$-D-glucopyranoside solution were added. After a $1 \mathrm{~h}$ reaction in an incubator, $50 \mu \mathrm{L}$ of a $0.1 \mathrm{~mol} / \mathrm{L}$ glycine sodium hydrate buffer solution $(\mathrm{pH}=10.7)$ was added to determine the fluorescence using the microplate reader. The measurement was performed at an excitation wavelength of $360 \mathrm{~nm}$ and an emission wavelength of $460 \mathrm{~nm}$.

\subsection{Effects of Fractions from Silica Gel Column Re-Fractionated Rice Koji Extracts on Cell Proliferation and $\beta$-GCase Activity in Cultured Human Keratinocytes}

Methanol fractions (1)-(7) of rice koji extract were separately dried and then dissolved in $6 \mathrm{~mL}$ of chloroform. The entire volume of dissolved lipid solution was added to $1 \mathrm{~g}$ of silica gel in a column (Strata SI-1, Phenomenex Inc., Torrance, CA, USA) equilibrated with chloroform and then eluted with $40 \mathrm{~mL}$ of chloroform/methanol (2:1). Subsequently, phospholipids other than lysophospholipids were eluted with $40 \mathrm{~mL}$ of chloroform/methanol (1:1). Each fraction was weighed after being dried under reduced pressure. Then, lysophospholipids were obtained with $40 \mathrm{~mL}$ of methanol. Each phospholipid or lysophospholipid fraction was separated and weighed after being dried under reduced pressure. Their concentrations were adjusted to $5 \mathrm{mg} / \mathrm{mL}$. Human keratinocytes with these fractions at a concentration of $50 \mu \mathrm{g} / \mathrm{mL}$ were cultured in $2 \%$ FBS-DMEM for three days, and the number of cells and $\beta$-GCase activity were measured in the same manner as in Section 2.3.

\subsection{TLC Analysis of Components in Rice Koji That Affect $\beta$-GCase Activity}

Methanol fractions (2)-(6) (chloroform/methanol 1:1 fractionation, $10 \mathrm{mg} / \mathrm{mL}$ ); methanol fractions (4)-(6) (methanol re-fractionation, $10 \mathrm{mg} / \mathrm{mL}$ ); 1,2-di-(cis-9-octadecenoyl)-sn-glycerin 3-phosphate sodium salt (PA_C18:1/C18:1, Sigma-Aldrich Corp., St. Louis, MO, USA; 10 mg/mL), as a standard of phosphatidic acid (PA); and oleoyl-L- $\alpha$-lysophosphatidic acid sodium salt (1-LPA_C18:1, Sigma-Aldrich Corp., St. Louis, MO, USA; $10 \mathrm{mg} / \mathrm{mL}$ ), as a standard of lysophosphatidic acid (LPA), were spotted on a thin-layer chromatography (TLC) plate (silica gel 60 TLC aluminum plates, Merck KGaA, Darmstadt, Germany). The plate was developed with chloroform/methanol/water/triethylamine (30:35:7:35 $(v / v))$. The developed plate was sprayed with molybdenum blue reagent and left at room temperature till turning a blue color. Phospholipids in the sample were estimated from the Rf value of the obtained spots. The spot density was analyzed by ImageJ. The method of preparing the molybdenum blue reagent (coloring reagent) was as follows. Solution A was prepared by adding $4.01 \mathrm{~g}$ of molybdenum trioxide $\left(\mathrm{MoO}_{3}\right)$ to $100 \mathrm{~mL}$ of $25 \mathrm{~mol} / \mathrm{L}$ $\mathrm{H}_{2} \mathrm{SO}_{4}$, which was then boiled gently until the solid dissolved. Solution $\mathrm{B}$ was prepared by adding $0.18 \mathrm{~g}$ of powdered molybdenum (Mo) to $50 \mathrm{~mL}$ of solution $\mathrm{A}$, which was then boiled gently for $15 \mathrm{~min}$ and allowed to cool. Equal amounts of the supernatants were mixed. After diluting three times with water, an equal volume of ethanol was added, and the solution was placed in a nebulizer.

\subsection{Effects of PA_C18:1/C18:1,PA_C16:0/C18:1, and 1-LPA_C18:1 on Cell Proliferation and $\beta$-GCase Activity in Cultured Human Keratinocytes}

PA_C18:1/C18:1,1-palmitoyl-2-oleoyl-sn-glycero-3-phosphatidic acid (PA_C16:0/C18:1) from the Cayman Chemical Company, Ann Arbor, MI, USA, and 1-LPA_C18:1 were used. Their concentrations were adjusted to $10 \mathrm{mg} / \mathrm{mL}, 1 \mathrm{mg} / \mathrm{mL}, 0.1 \mathrm{mg} / \mathrm{mL}$, and $0.01 \mathrm{mg} / \mathrm{mL}$ with ethanol, respectively. The effect of PA_C18:1/C18:1, PA_C16:0/C18:1, and 1-LPA_C18:1 on the number of cells and $\beta$-GCase activity in cultured human keratinocytes was examined as described in Section 2.3.

\subsection{Effects of the PA and LPA Fractions of Rice Koji on TEWL on a Three-Dimensional Human Epidermis Model}

An agar plate was placed on a warmer set at $32{ }^{\circ} \mathrm{C}$ in a room with a temperature of $22{ }^{\circ} \mathrm{C}$ and a humidity of $40 \%$, and a three-dimensional human epidermis model, which had been cultured for four days in the presence or absence of the PA fraction (5) or LPA fraction (5) of rice $k o j i ~(10 \mu \mathrm{g} / \mathrm{mL}$, 
$100 \mu \mathrm{g} / \mathrm{mL}$ in a solvent of ethanol:water (1:99)), was placed on the agar plate inlay. The transepidermal water loss (TEWL) was measured with a Tewameter TM 210 (Courage and Khazaka Electronic GmbH, Köln, Germany) using a probe for 24-well culture inserts.

\subsection{Effects of PA and LPA on TEWL in a Three-Dimensional Human Epidermis Model}

An agar plate was placed on a warmer set at $32{ }^{\circ} \mathrm{C}$ in a room with a temperature of $22{ }^{\circ} \mathrm{C}$ and a humidity of $40 \%$, and a three-dimensional human epidermis model, which had been cultured for four days in the presence or absence of PA_C18:1/C18:1, PA_C16:0/C18:1, or 1-LPA_C18:1 $(10 \mu / \mathrm{mL}$, $100 \mu \mathrm{g} / \mathrm{mL}$ in a solvent of ethanol:water (1:99)), was placed on the agar plate inlay. The TEWL was measured with the Tewameter TM210 using the probe for 24-well culture inserts [12].

2.9. Effects of the PA and LPA Fractions of Rice Koji, PA_C18:1/C18:1, PA_C16:0/C18:1, and 1-LPA_C18:1 on the Amount of $\beta$-GCase mRNA in the Three-Dimensional Human Epidermis Model

We investigated the amount of $\beta$-GCase mRNA involved in ceramide synthesis using a human epidermal model cultured for four days in the absence or presence of the PA fraction of rice koji, the LPA fraction, PA_C18:1/C18:1, PA_C16:0/C18:1, or 1-LPA_C18:1 $(10 \mu \mathrm{g} / \mathrm{mL}, 100 \mu \mathrm{g} / \mathrm{mL}$ in a solvent of ethanol:water (1:99)). RNA extraction was performed using the RNeasy Protect Mini Kit (RNeasy Mini kit, Qiagen GmbH, Hilden, Germany) according to the manufacturer's instructions. cDNA conversion from the extracted RNA was performed using the One Step SYBR ${ }^{\circledR}$ Prime Script ${ }^{\mathrm{TM}}$ RT-PCR Kit II (Takara Bio Inc., Shiga, Japan) according to the package insert. The expression level of mRNA was measured using real-time PCR (Applied Biosystems 7900HT, Thermo Fisher Scientific Inc., Waltham, MA, USA). GAPDH was used as a reference gene for normalization. Primers were purchased from Qiagen. Each experiment was performed thrice. In the analysis, a threshold cycle $\mathrm{Ct}$ was obtained, the difference between the $\mathrm{Ct}$ value of the housekeeping gene and the $\mathrm{Ct}$ value of the target gene $(\Delta \mathrm{Ct}$ : (target gene $\mathrm{Ct})-($ housekeeping gene $\mathrm{Ct})$ ) was obtained, and the ratio of gene expression was calculated from the difference in $\Delta \mathrm{Ct}$ between samples $(\Delta \Delta \mathrm{Ct})$.

\subsection{Measurement of the PA and LPA Contents in Steamed Rice and Rice Koji}

Five hundred microliters of methanol and $500 \mu \mathrm{L}$ of chloroform were added to $20 \mathrm{mg}$ of lyophilized powder of steamed rice and rice koji, and after shaking and centrifugation, $100 \mu \mathrm{L}$ of supernatant was collected. Then, $100 \mu \mathrm{L}$ of a methanol solution of a PA measurement internal standard (PA_16:0 D 31/18: $1(500 \mathrm{ng} / \mathrm{mL}))$ was added to this supernatant sample to yield an analytical sample for PA measurement. In addition, $300 \mu \mathrm{L}$ of the supernatant was taken, and $150 \mu \mathrm{L}$ of the methanol solution of internal standard 1-LPA_17:0, 2-LPA_17:0 $(50 \mathrm{ng} / \mathrm{mL})$ was added to prepare an analytical sample for LPA measurement. Liquid chromatography (LC) and mass spectrometry (MS) conditions are shown below.

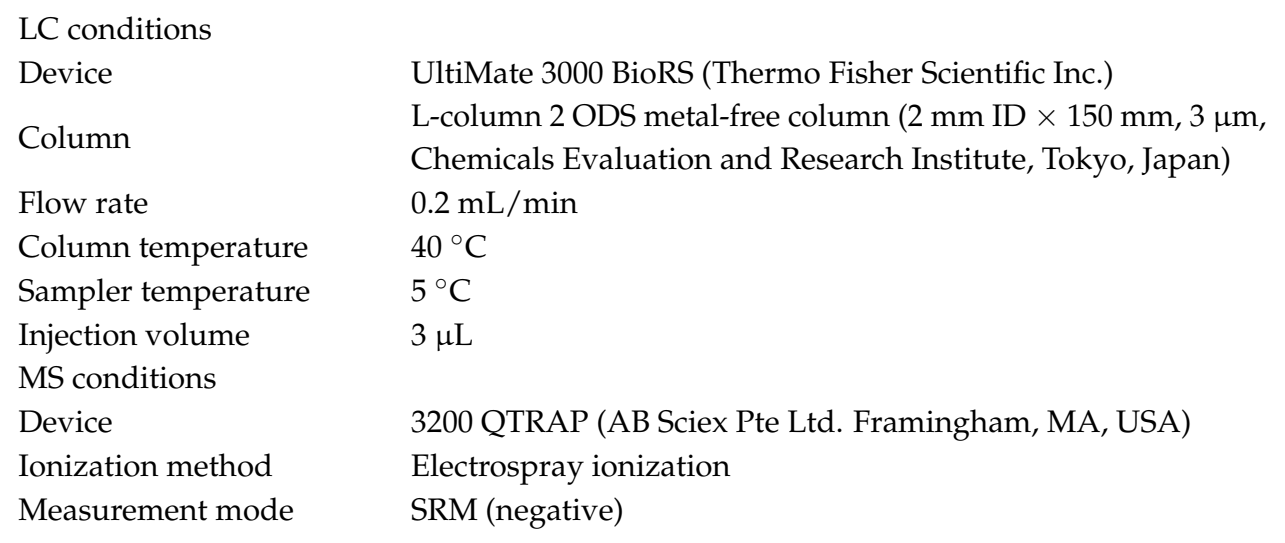


The analysis software Analyst 1.6.1 (AB Sciex) was used for peak detection. The detection limit was set to a signal noise ratio $(\mathrm{S} / \mathrm{N})$ of 3 . The area value of the detected peak was divided by the peak area value of the internal standard (PA_16:0 D 31/18:1) to calculate the ratio. The approximate concentration of each molecular species in the sample was calculated using the obtained peak area ratio. The coefficient of variation (C.V. \%) for five measurements of the peak area ratio (analysis sample/internal standard) of each molecular species was $6.9 \pm 2.5$ (mean \pm standard deviation).

\subsection{Measurement of the Relative LPA Contents in Steamed Rice and Rice Koji}

To prepare the lysophospholipid fraction, $15 \mathrm{~mL}$ of chloroform/methanol (2:1) was added to $5 \mathrm{~g}$ of each of the three types of steamed rice and rice $k o j i$, and the mixtures were stirred and extracted at room temperature for $1 \mathrm{~h}$. They were divided into soluble and solid components by filtration, and distilled water was added while stirring to make a chloroform/methanol/water solution (8:4:3 volume ratio). The sample was left undisturbed, and the lower layer (chloroform layer, total lipid fraction) was collected. The total amount of collected lipids was added to a silica gel column (Strata SI-1 $100 \mathrm{mg}$ (Phenomenex Inc.), gel volume $1 \mathrm{~mL}$ ) equilibrated with chloroform; neutral lipids were then eluted using $10 \mathrm{~mL}$ of chloroform, and glycolipids were eluted using $40 \mathrm{~mL}$ of acetone. Finally, a total phospholipid fraction was obtained with $10 \mathrm{~mL}$ of methanol. Total phospholipids were dried and then dissolved in $1 \mathrm{~mL}$ of chloroform. The dissolved phospholipid solution was added in its entirety to a silica gel column (Strata SI-1 $100 \mathrm{mg}$, Phenomenex Inc.) equilibrated with chloroform, and phospholipids other than lysophospholipids were eluted with $10 \mathrm{~mL}$ of chloroform/methanol (1:1). Subsequently, a lysophospholipid fraction was obtained with $10 \mathrm{~mL}$ of methanol. This fraction was dried under reduced pressure and dissolved in $100 \mu \mathrm{L}$ of $10 \%$ Triton X-100-isopropanol. For a determination of LPA concentration, the lysophospholipid fraction was methyl-esterified using a fatty acid methyl esterification kit (Nacalai Tesque, Inc., Kyoto, Japan), and the products were analyzed by GC-flame ionization detection (FID) (TC-WAX, GL Sciences Inc., Tokyo, Japan). 1-LPA_C18:1 (Tocris Bioscience, Bristol, UK) was used as a standard. The peak area ratio of each molecular species with a C.V. below $15 \%$ for three measurements was adopted.

\subsection{Statistical Analysis}

Statistical analysis was performed using t-tests run with MS Excel. Differences with a $p$ value less than $5 \%$ were statistically significant $\left({ }^{*} p<0.05,{ }^{* *} p<0.01,{ }^{* * *} p<0.001\right)$, and there was no significant difference (ns) above $5 \%$. In addition, when the ratio was greater than $5 \%$ but less than $10 \%$, it was considered to be exhibiting a tendency $\left({ }^{+} p<0.1\right)$.

\section{Results}

\subsection{Effects of Rice Koji Extract Fractions on Cell Proliferation and $\beta$-GCase Activity in Cultured Human Keratinocytes}

Figure 1 shows the effects of the chloroform, acetone, and methanol fractions of rice koji extract on the number of cells and $\beta$-GCase activity in cultured human keratinocytes. Significantly more cells were observed in treatments with methanol fractions (2)-(7) of the rice koji extract than in the control (Figure 1a). In addition, a significant enhancement in $\beta$-GCase activity was confirmed in cells treated with methanol fractions (5) and (6) of the rice koji extract (Figure 1b). The chloroform and acetone fractions of rice koji extract had no such effect. 
(a)
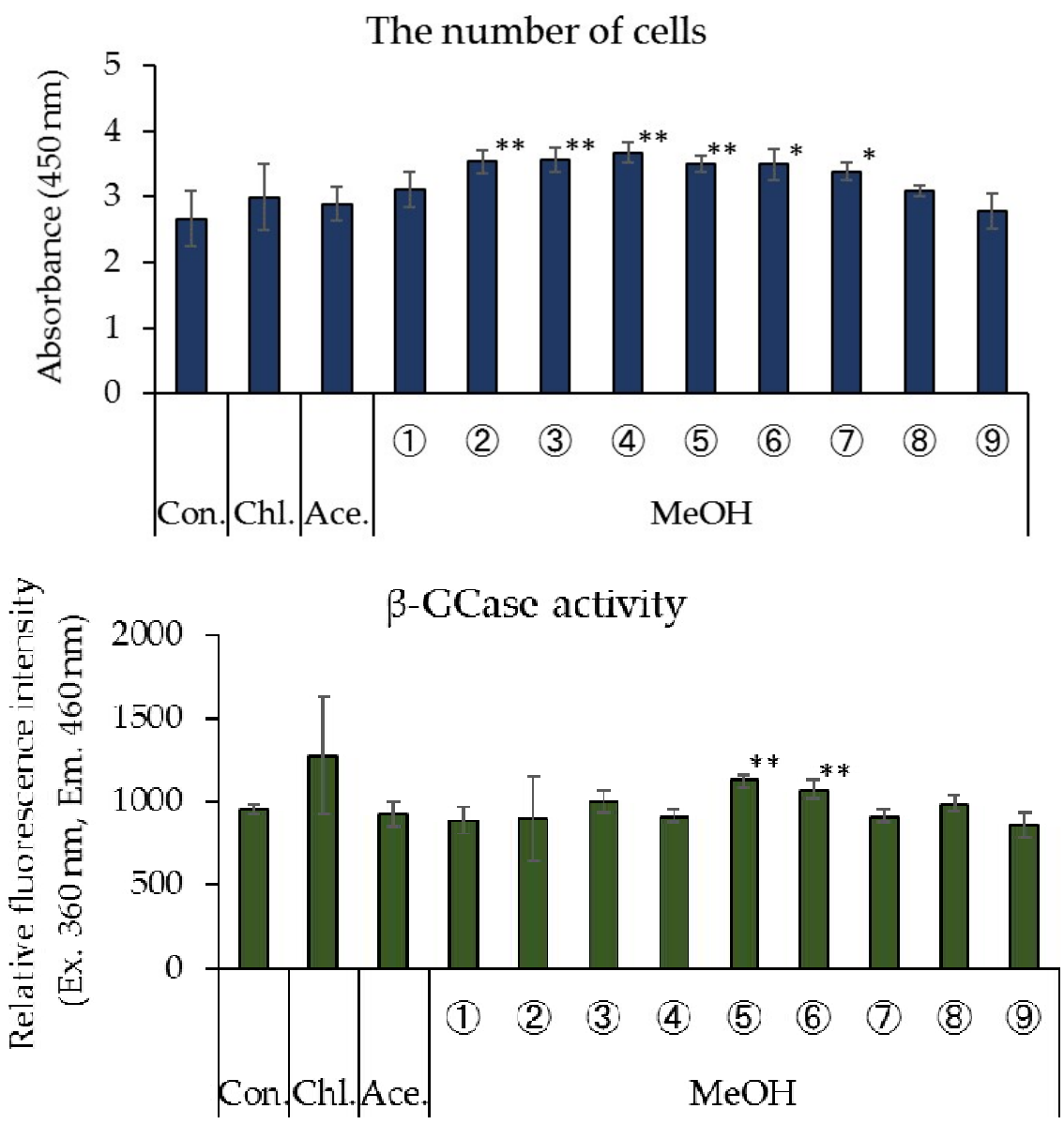

Figure 1. Effects of fractions of rice koji extracts on cell proliferation and $\beta$-GCase activity in cultured human keratinocytes. (a) The number of cells, (b) $\beta$-GCase activity, $n=4$, mean \pm standard deviation (S.D.), ${ }^{+} p<0.1$ vs. control, ${ }^{*} p<0.05$ vs. control, and ${ }^{* *} p<0.01$ vs. control.

\subsection{Effects of Fractions from Silica Gel Column Re-Fractionated Rice Koji Extracts on Cell Proliferation and $\beta$-GCase Activity in Cultured Human Keratinocytes}

Figure 2 shows the effect of silica gel column re-fractionated rice koji extracts on the number of cells and $\beta$-GCase activity in cultured human keratinocytes. A significant increase in the number of cells was confirmed in treatments with silica column fractions (2), (3), and (5) (chloroform/methanol 1:1 re-fractionation) of the methanol fractions of rice koji extract, and a tendency to promote cell proliferation was observed in fraction (1) (Figure 2a). In addition, a significant increase in the number of cells was observed in treatments with silica gel column fraction (1) (methanol re-fractionation) of the methanol fractions of rice koji extract (Figure 2a). A significant increase in $\beta$-GCase activity was observed in cells treated with fractions (2)-(7) of the silica gel column fractionations (chloroform/methanol 1:1 re-fractionation) from the methanol fractions of rice koji extract (Figure 2b). In addition, a significant enhancement in $\beta$-GCase activity was confirmed in cells treated with silica gel column fractions (2)-(6) (methanol re-fractionation) of the methanol fractions of rice koji extract, and a tendency to promote $\beta$-GCase activity was observed in fraction 7 (Figure $2 b$ ). 
(a)
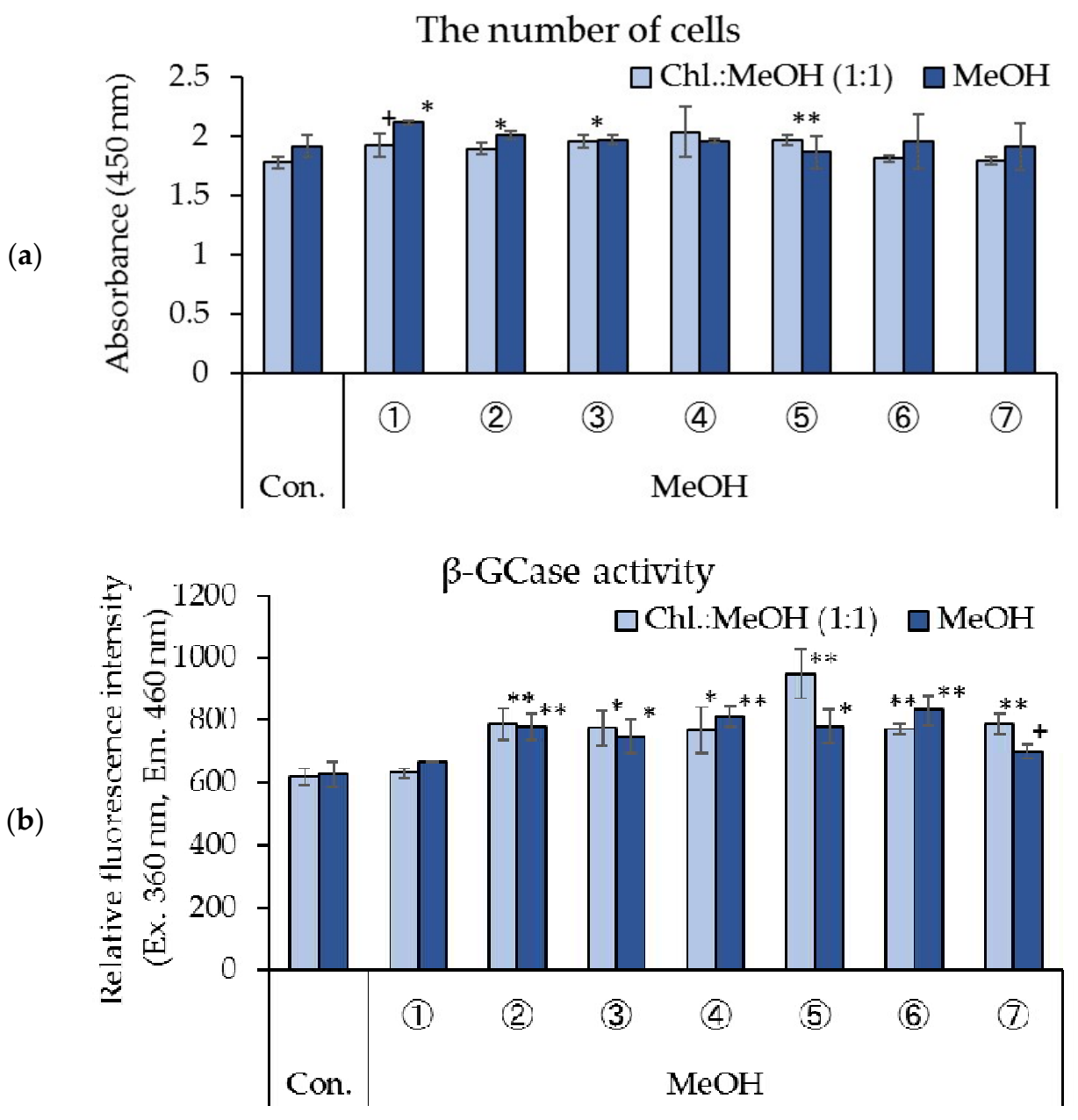

Figure 2. Effects of fractions from silica gel column re-fractionated rice koji extract on cell proliferation and $\beta$-GCase activity in cultured human keratinocytes. (a) The number of cells, (b) $\beta$-GCase activity, $n=4$, mean \pm S.D., ${ }^{+} p<0.1$ vs. control, ${ }^{*} p<0.05$ vs. control, and ${ }^{* *} p<0.01$ vs. control.

\subsection{TLC Analysis of Components of Rice Koji Extract That Induce $\beta$-GCase Activity}

In Figure 3a, the TLC images of the chloroform and acetone extracts, methanol fractions (2)-(7) (chloroform/methanol 1:1 re-fractionation of rice koji extract) and methanol fractions (2)-(7) (methanol re-fractionation of rice koji extract) are shown. The presence of PA in methanol fractions (2)-(6) (chloroform/methanol 1:1 re-fractionation of rice koji extract) and LPA in methanol fractions (4)-(6) (methanol re-fractionation of rice koji extract) was confirmed. As a result of the analysis of spot density with ImageJ, the presence of PA in methanol fraction (5) (chloroform/methanol 1:1 re-fractionation of rice koji extract) and of LPA in methanol fractions (4) and (5) (methanol refraction of rice koji extract) was confirmed in a majority of cases (Figure $3 b$ ). 
(a)
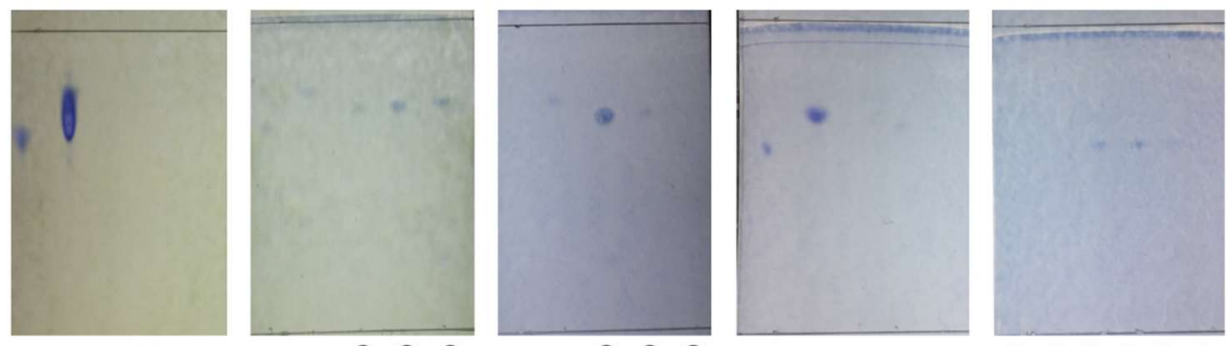

LPA PA Chl. Act. LPA PA (2) (3) (4) LPA PA (5) (6) (7)

LPA PA Chl. Act.

(2) (3) (4) (5) (6) (7)

Chl:MeOH (1:1)

$\mathrm{MeOH}$

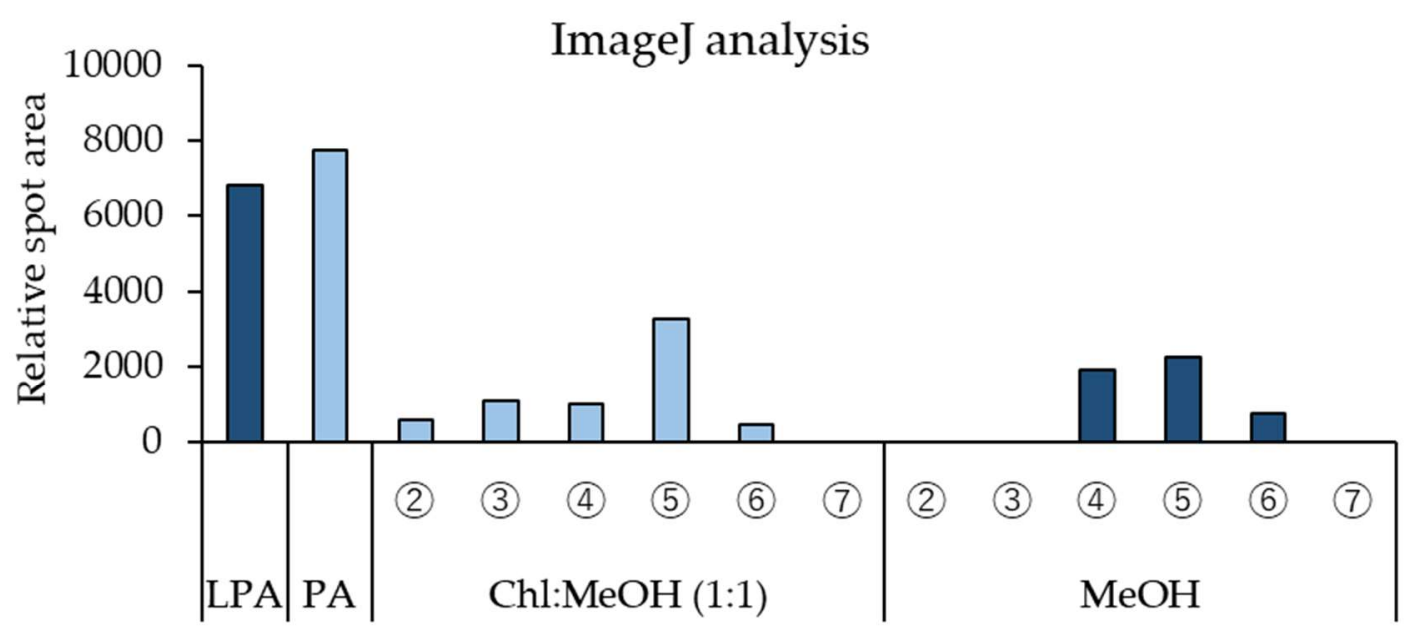

Figure 3. TLC (thin-layer chromatography) analysis of components in rice koji extract that increase $\beta$-GCase activity. (a) TLC image, (b) analysis of spot density with ImageJ. LPA: 1-LPA_C18:1, LA: PA_C18:1/C18:1.

3.4. Effects of PA_C18:1/C18:1 and 1-LPA_C18:1 on Cell Proliferation and $\beta$-GCase Activity in Cultured Human Keratinocytes

Figure 4 shows the effects of PA_C18:1/C18:1 and 1-LPA_C18:1 on the number of cells and $\beta$-GCase activity in cultured human keratinocytes. Treatment with PA_C18:1/C18:1 (10 $\mu \mathrm{g} / \mathrm{mL}$, $100 \mu \mathrm{g} / \mathrm{mL})$ and 1-LPA_C18:1 $(100 \mu \mathrm{g} / \mathrm{mL})$ resulted in a significant increase in the number of cells (Figure 4a). In addition, a significant enhancement in $\beta$-GCase activity was observed in cells treated with either PA_C18:1/C18:1 $(10 \mu \mathrm{g} / \mathrm{mL}, 100 \mu \mathrm{g} / \mathrm{mL})$ or 1-LPA_C18:1 $(10 \mu \mathrm{g} / \mathrm{mL}, 100 \mu \mathrm{g} / \mathrm{mL})$. Treatment with PA_C18:1/C18:1 $(1 \mu \mathrm{g} / \mathrm{mL})$ also demonstrated a tendency towards increased $\beta$-GCase activity (Figure 4b). 


\section{The number of cells $\square$ PA_C18:1/C18:1}

$\square$ 1-LPA_C18:1

(a)

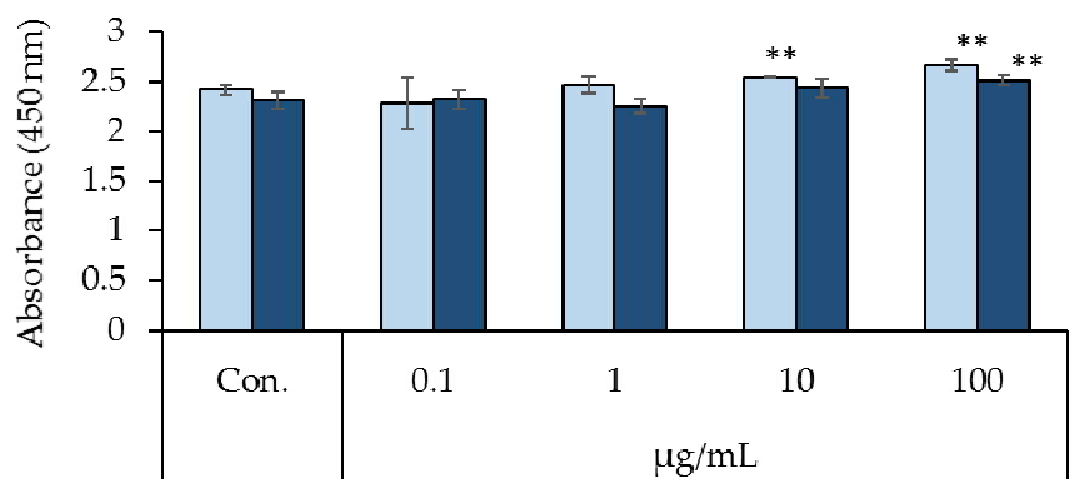

(b)

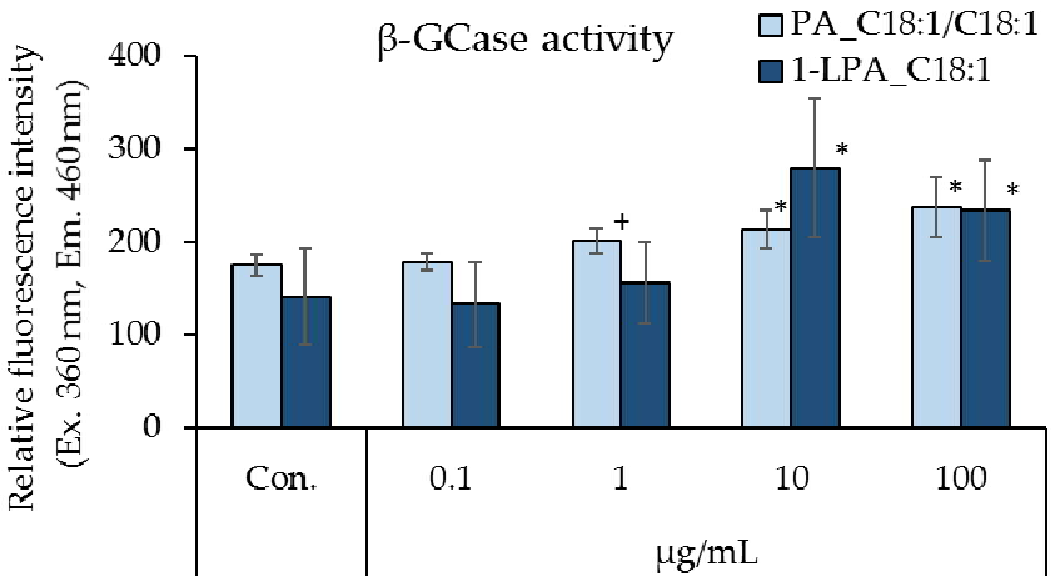

Figure 4. Effects of PA_C18:1/C18:1 and 1-LPA_C18:1 on cell proliferation and $\beta$-GCase activity in cultured human keratinocytes. (a) Number of cells, (b) $\beta$-GCase activity; $n=4$, mean \pm S.D., ${ }^{+} p<0.1$ vs. control, ${ }^{*} p<0.05$ vs. control, and ${ }^{* *} p<0.01$ vs. control.

\subsection{Effects of the PA and LPA Fractions of Rice Koji Extract, PA_C18:1/C18:1, PA_C16:0/C18:1, and} 1-LPA_C18:1 on the TEWL in the Three-Dimensional Human Epidermal Model

Figure 5a shows the TEWL, which is the amount of moisture that transpired from the stratum corneum in the three-dimensional human epidermal model cultured for four days in the presence or absence of the PA and LPA fractions of rice koji extract. The TEWL from human epidermal models cultured in the presence of methanol fraction (5) (chloroform/methanol 1:1 re-fractionation, $10 \mu \mathrm{g} / \mathrm{mL}$, $100 \mu \mathrm{g} / \mathrm{mL}$ ) as the PA fraction and in the presence of methanol fraction (5) (methanol re-fractionation, $100 \mu \mathrm{g} / \mathrm{mL}$ ) as the LPA fraction was significantly lower than that in the absence of these fractions (control). In addition, the TEWL from human epidermal models cultured in the presence of the LPA fraction $(10 \mu \mathrm{g} / \mathrm{mL})$ had a tendency to be lower than that in the control (Figure $5 \mathrm{a}$ ).

Furthermore, Figure $5 b$ shows the TEWL from human epidermal models cultured for four days in the presence or absence of either PA or LPA. The TEWL from human epidermal models cultured in the presence of PA_C18:1/C18:1 $(10 \mu \mathrm{g} / \mathrm{mL}, 100 \mu \mathrm{g} / \mathrm{mL})$, PA_C16:0/C18:1 $(10 \mu \mathrm{g} / \mathrm{mL}, 100 \mu \mathrm{g} / \mathrm{mL})$, and 1-LPA_C18:1 $(100 \mu \mathrm{g} / \mathrm{mL})$ was significantly lower than that in the absence of these fractions (control), and the TEWL in the epidermis model cultured for four days in the presence of 1-LPA_C18:1 $(10 \mu \mathrm{g} / \mathrm{mL})$ showed a tendency to be lower than the TEWL in the control (Figure $5 \mathrm{~b}$ ).

The transpiration of moisture from the stratum corneum was significantly suppressed by PA and LPA. 
(a)
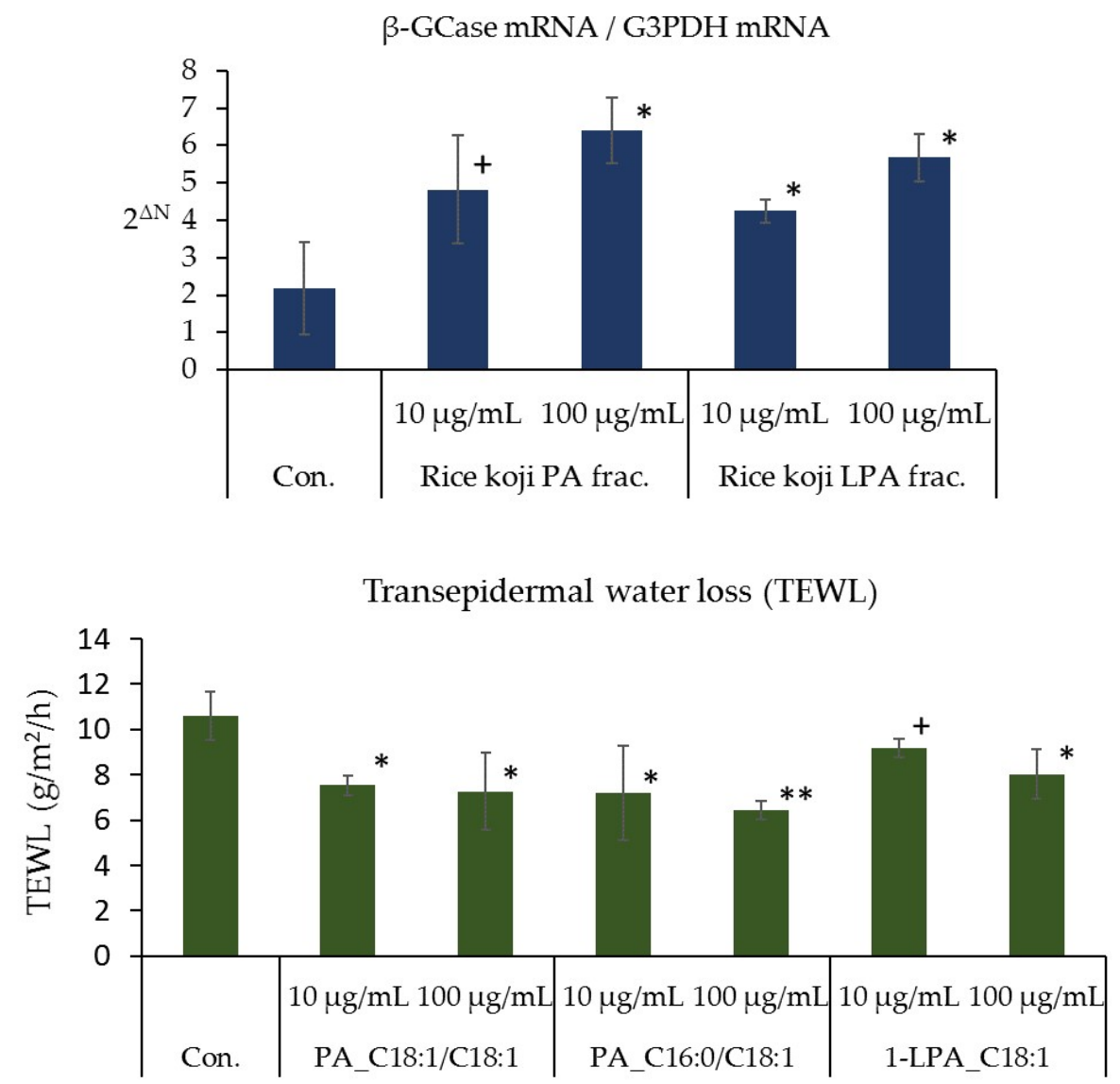

Figure 5. Effects of the PA and LPA fractions of rice koji extract, PA_C18:1/C18:1, PA_C16:0/C18:1, and 1-LPA_C18:1 on the TEWL from the three-dimensional epidermal model. (a) Effects of the PA and LPA fractions of rice koji extract on the TEWL, (b) effects of PA_C18:1/C18:1, PA_C16:0/C18:1, and 1-LPA_C18:1 on the TEWL; $n=3$, mean \pm S.D., ${ }^{+} p<0.1$ vs. control, ${ }^{*} p<0.05$ vs. control, and ${ }^{* *}$ $p<0.01$ vs. control.

3.6. Effects of the PA and LPA Fractions of Rice Koji Extract, PA_C18:1/C18:1, PA_C16:0/C18:1, and 1-LPA_C18:1 on the Expression Level of $\beta$-GCase mRNA in the Three-Dimensional Human Epidermis Model

The level of $\beta$-GCase mRNA in the three-dimensional human epidermis models cultured for four days in the presence of either rice koji methanol fraction (5) (chloroform/methanol 1:1 re-fractionation, PA fraction $100 \mu \mathrm{g} / \mathrm{mL}$ ) or methanol fraction (5) (methanol re-fractionation, LPA fraction $10 \mu \mathrm{g} / \mathrm{mL}$, $100 \mu \mathrm{g} / \mathrm{mL}$ ) was significantly higher than that in the control (Figure 6a). The mRNA level of $\beta$-GCase in the epidermal model cultured for four days in the presence of methanol fraction (5) (chloroform/methanol 1:1 re-fractionation, PA fraction $10 \mu \mathrm{g} / \mathrm{mL}$ ) tended to be higher than the mRNA level of $\beta$-GCase in the control (Figure 6a). Furthermore, the level of $\beta$-GCase mRNA in the epidermal models cultured for four days in the presence of PA_C18:1/C18:1 $(100 \mu \mathrm{g} / \mathrm{mL})$, PA_C16:0/C18:1 $(100 \mu \mathrm{g} / \mathrm{mL})$, or 1-LPA_C18:1 $(100 \mu \mathrm{g} / \mathrm{mL})$ was significantly higher than that found in the control epidermal model (Figure $6 \mathrm{~b}$ ). The level of $\beta$-GCase mRNA in the models cultured for four days in the presence of PA_C18:1/C18:1 $(10 \mu \mathrm{g} / \mathrm{mL})$, PA_C16:0/C18:1 $(10 \mu \mathrm{g} / \mathrm{mL})$, or 1-LPA_C18:1 $(10 \mu \mathrm{g} / \mathrm{mL})$ tended to be higher than that of the control model (Figure $6 \mathrm{~b}$ ). 
(a)

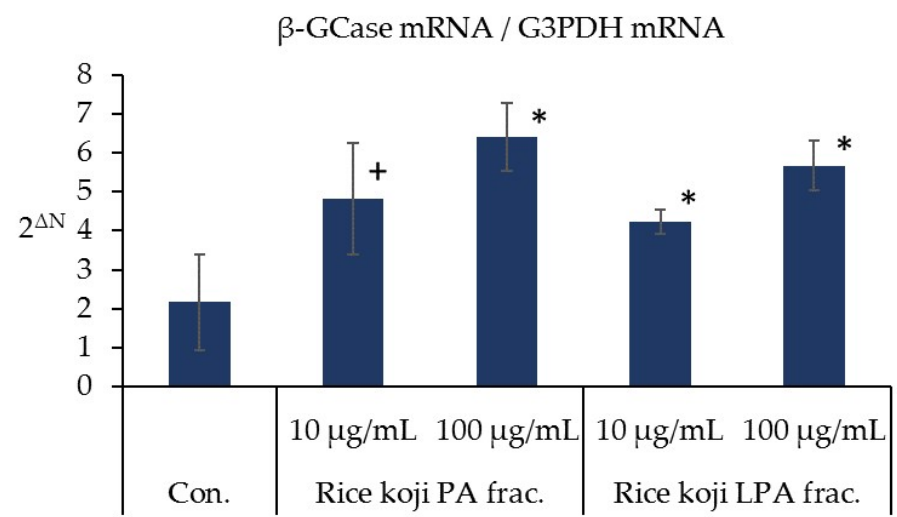

(b)

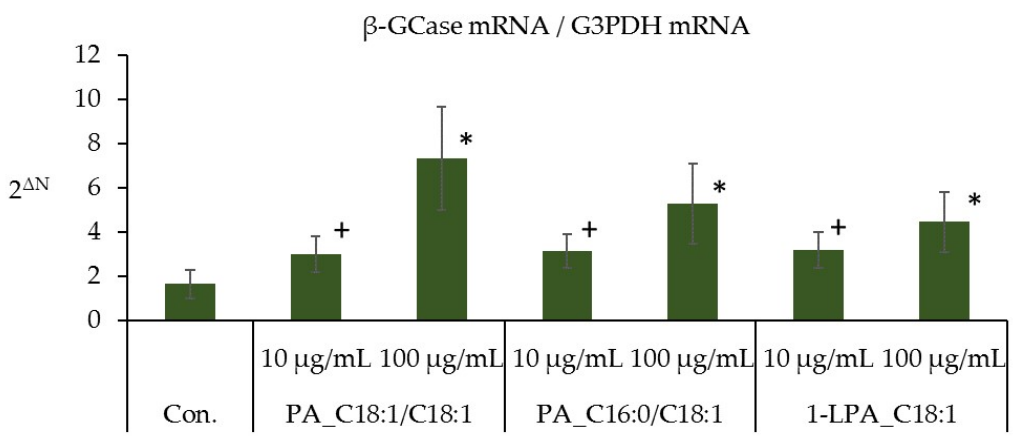

Figure 6. Effects of the PA and LPA fractions of rice koji extract, PA_C18:1/C18:1, PA_C16:0/C18:1, and 1-LPA_C18:1 on $\beta$-GCase mRNA expression in cultured human keratinocytes. (a) Effects of the PA and LPA fractions of rice koji extract on the level of $\beta$-GCase mRNA, (b) effects of PA_C18:1/C18:1, PA_C16:0/C18:1, and 1-LPA_C18:1 on the level of $\beta$-GCase mRNA; $n=3$, mean \pm S.D., ${ }^{+} p<0.1$ vs. control, ${ }^{*} p<0.05$ vs. control, and ${ }^{* *} p<0.01$ vs. control.

\subsection{Measurement of the PA and LPA Contents in Steamed Rice and Rice Koji}

The content of PA in each molecular species of steamed rice and rice koji was measured, and the results are shown in Figure 7a. The total PA in rice koji was $973.9 \mathrm{ng} / \mathrm{mg}$ dry weight, which was 17.5 times higher than the total PA in steamed rice ( $55.5 \mathrm{ng} / \mathrm{mg}$ of dry weight). PA_18:2/18:2 is the most common molecular species, followed by, in decreasing order, PA_16:0/18:2, PA_18: 1/18:2, and PA _16:0/18:1 (Figure 7a). The LPA contents of steamed rice and rice koji are shown in Figure 7b. LPA was not detected in steamed rice, but LPA at a concentration of $29.6 \mathrm{ng} / \mathrm{mg}$ dry weight was confirmed in rice koji. In addition, the 2-LPA content in rice koji was 14 times that of 1-LPA. The 2 -LPA_18:2 species was the most frequently found 2-LPA, followed by 2-LPA_18:1. Little 1-LPA was found. 
(a)

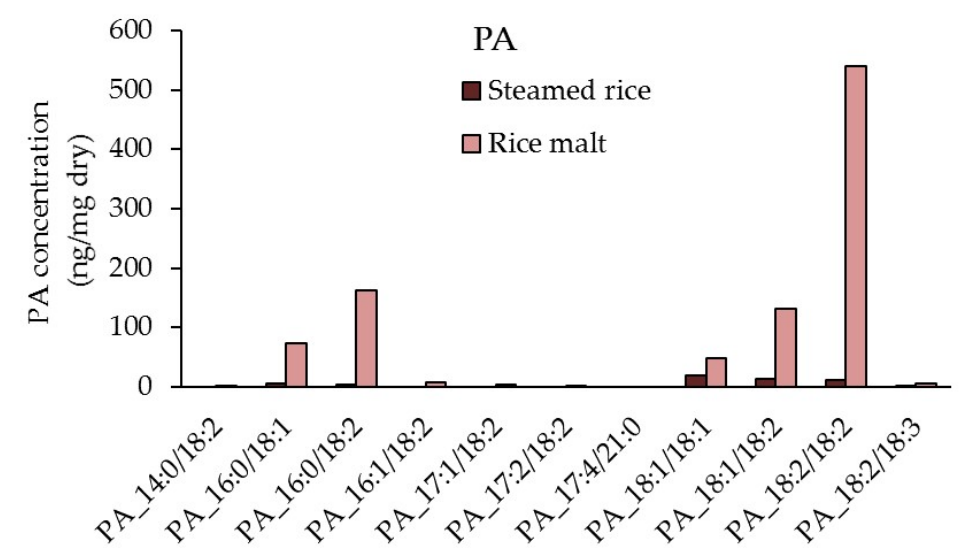

(b)
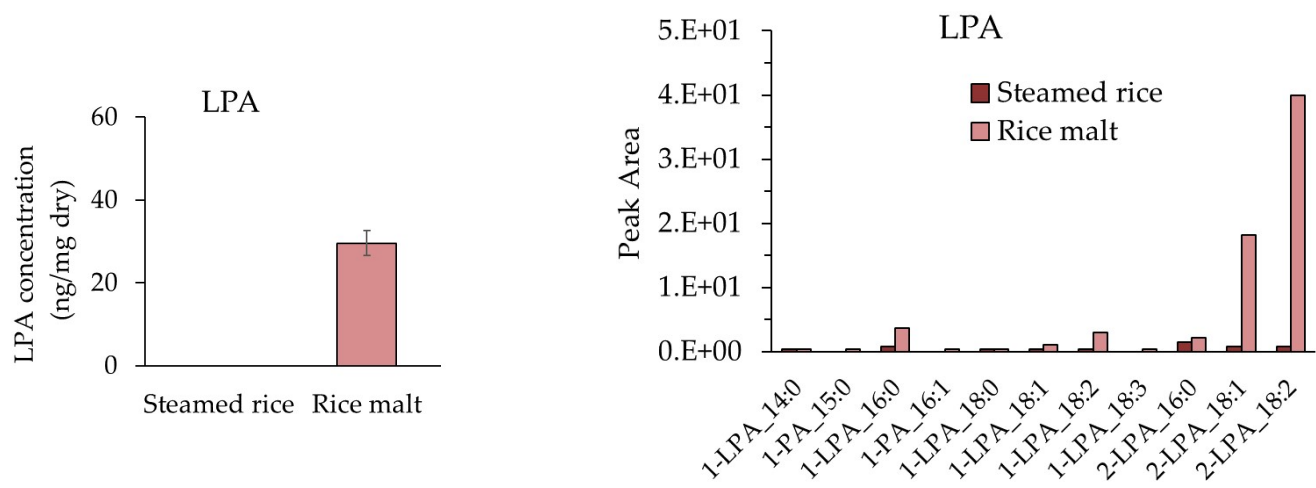

Figure 7. PA and LPA contents in steamed rice and rice koji. (a) Molecular species content of PA in steamed rice and rice koji, (b) LPA contents in steamed rice and rice koji (left), and molecular species content of LPA in rice koji relative to that in steamed rice (right).

\subsection{Measurement of the PC and LPC Contents in Steamed Rice and Rice Koji}

The contents of phosphatidylcholine (PC) and lysophosphatidylcholine (LPC) in steamed rice and rice koji are shown in Figure 8. Although PC was hardly detected in steamed rice, PC_18:2/18:2 was the most abundant PC in rice koji, followed by PC_18:1/18:2 and PC_16:0/18:2 (Figure 8a). Two types of 1-LPC were present in steamed rice: 1-LPC_16:0 and 1-LPC_18:2. Meanwhile, 1-LPC was also present in rice koji, and 1-LPC_16:0 and 1-LPC_18:2 were abundant. Both 2-LPC_16:0 and 2-LPC_18:2 were less abundant in rice koji than the other types of LPC (Figure 8b). 
(a)

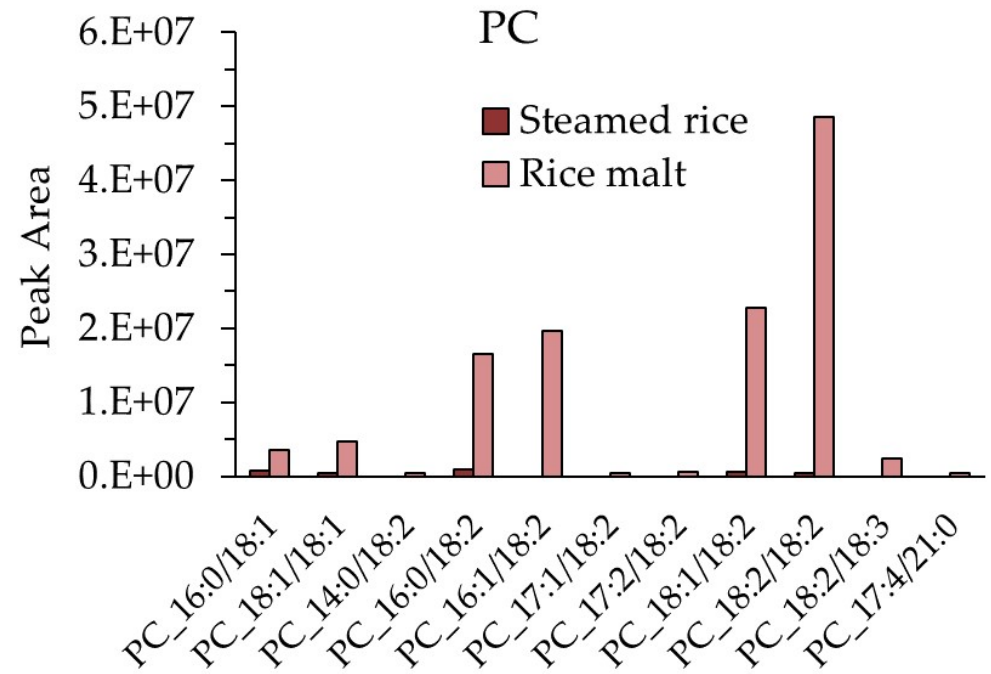

(b)

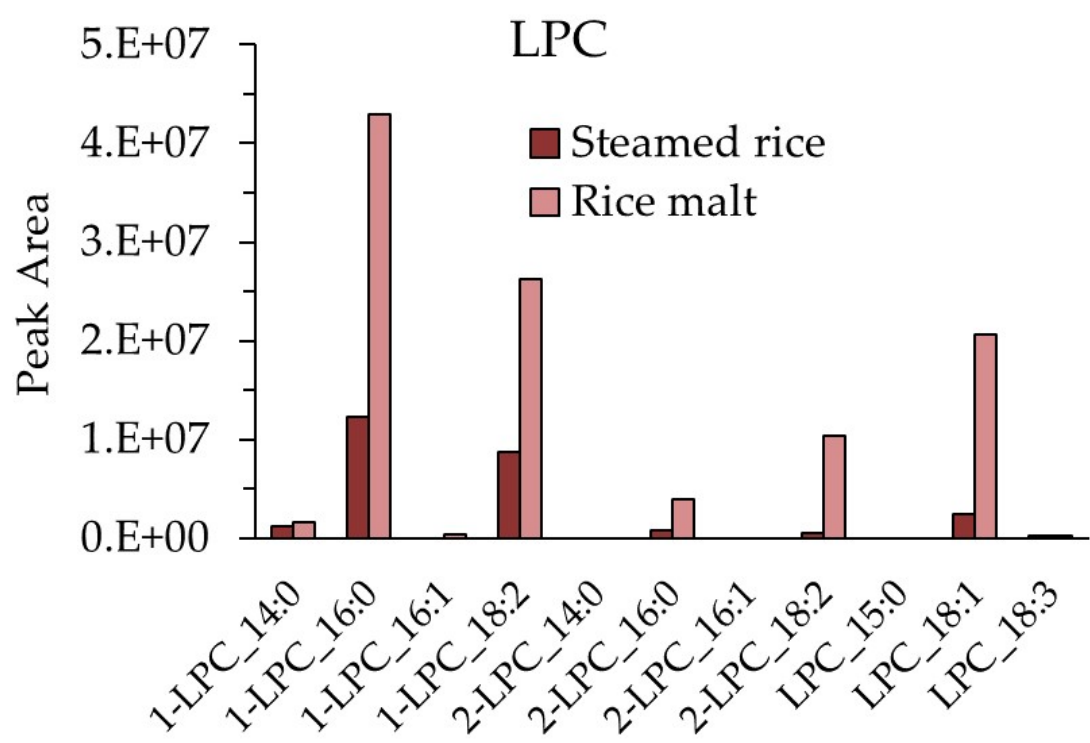

Figure 8. PC and LPC contents in steamed rice and rice koji. (a) Relative molecular species content of PC in steamed rice and rice koji and (b) relative molecular species content of LPC in steamed rice and rice koji.

\section{Discussion}

The stratum corneum intercellular lipids, which extend into the intercellular space of the stratum corneum (extracellular stratum corneum lipids), act as a barrier between the epidermis and the air of the outside world and are critical to preventing the transpiration of moisture from inside the body and moisture ingression from outside the body. When this barrier is damaged, excessive evaporation occurs, and the stratum corneum becomes dehydrated, while further deterioration causes allergic reactions in the skin, such as rough skin and atopic dermatitis [13-15]. The intercellular lipids consist of ceramides $(37 \%)$, cholesterols (32\%), long-chain fatty acids (16\%), and cholesterol esters $(15 \%)$ and form a multilayered lamellar lipid structure [16]. Among these components, ceramides are particularly important in the stratum corneum and are present in amounts 30 times or greater in the stratum corneum than in other organs. The stratum corneum ceramides are characterized not only by their large quantity, but also by the presence of various kinds of molecules $[17,18]$. Acylceramide, which 
is important for skin barrier function, is produced by $\beta$-GCase from acylglucosylceramide $[19,20]$. In addition, some ceramides are produced from both glucosylceramide and sphingomyelin [21,22].

We showed that the mRNA expression and activity of $\beta$-GCase, which is an enzyme involved in ceramide synthesis in the stratum corneum, increases with exposure to rice miso extract [1]. The levels of phytosphingosine- and sphingosine-type ceramides increase after such exposure [1]. During the fermentation of miso, various functional substances are produced by the enzymatic action of various fermenting microorganisms. For example, miso contains functional substances, such as essential fatty acids (linoleic acid and linolenic acid), and acylphosphatidic acid is produced by Rhizopus oryzae [23]. In this study, to investigate whether ceramide synthesis is involved in the skin improvement effects of rice koji, we examined the effects of the lipid component of rice koji on the mRNA level and activity of $\beta$-GCase in cultured keratinocytes. We found that both the mRNA level and activity of $\beta$-GCase were increased in cells treated with a methanol fraction of rice koji extract and with PA and LPA. In addition, when a methanol fraction of rice koji extract, PA, and LPA were allowed to act on the three-dimensional human epidermal skin model, a decrease in TEWL and increases in $\beta$-GCase activity and $\beta$-GCase mRNA expression occurred. On the other hand, the chloroform and acetone fractions of rice koji extract had no such effect. Rice (Oryza sativa L.) contains phospholipase A1 and phospholipase A2 [24], and rice bran oil contains phospholipase D $[25,26]$. Since steamed rice is used for the production of rice koji, these enzymes are thought to be inactivated. On the other hand, A. oryzae produces phospholipase A1 [27,28]. Rice bran oil contains phospholipids [29], and rice contains many PCs, which are phospholipids, and LPC_16:0 (3.0 to $4.7 \mu \mathrm{g} / \mathrm{mL})$ and LPC_18:2 (0.8 to $2.2 \mu \mathrm{g} / \mathrm{mL})$, which are both lysophospholipids [30].

In our study, PA and LPA were included in rice koji, and since their concentrations were higher in rice koji than in steamed rice, the source of phospholipids was thought to be the rice. The abundance of 2-LPA was 14 times greater than that of 1-LPA in rice koji. The 2-LPA_18:2 species was the most frequently found, followed by 2-LPA_18:1, and the 1-LPA level was low in rice koji. From these results, PA was considered to be produced from PC by phospholipase D of A. oryzae, and 2-LPA was produced from PA by phospholipase A1. Furthermore, these results indicated that the activity of phospholipase A1 of A. oryzae was higher than that of phospholipase A2. However, since the PA content in rice koji was 10 times greater than the LPA content, the phospholipase A1 activity of $A$. oryzae was not thought to be high. In addition, 2-LPA may be produced by phospholipase D of $A$. oryzae from the 2-LC produced by phospholipase A1 of $A$. oryzae, but the pathway by which 1-LPA is produced from 1-LC via phospholipase $\mathrm{D}$ of $A$. oryzae contributes less. The activity of phospholipase $\mathrm{D}$ of orthologous genes has not been verified in A. oryzae [31], and further investigating the variations in phospholipase $\mathrm{D}$ for each $A$. oryzae strain is necessary.

\section{Conclusions}

The methanol fraction of rice koji extract contains PA and LPA, both of which increase the mRNA expression and activity of $\beta$-GCase in cultured human epidermal keratinocytes. Therefore, PA and LPA are thought to be among the active ingredients in rice koji that increase the $\beta$-GCase levels in human epidermal keratinocytes. The total PA in rice $k o j i$ was $973.9 \mathrm{ng} / \mathrm{mg}$ dry weight, which was 17.5 times higher than that in the steamed rice used as the source of rice koji, and contained several molecular species, of which PA_18:2/18:2 was the most abundant. The total LPA in rice koji was $29.6 \mathrm{ng} / \mathrm{mg}$ dry weight, and 2-LPA_18:2 was the most abundant. Based on these findings, foods containing rice $k o j i$ (which includes high levels of PA and LPA) can presumably function in improving the moisture content, viscoelasticity, and texture of human skin.

Author Contributions: K.M. conceived and designed the experiments; Y.O. performed the experiments; K.M. and Y.O. analyzed the data; K.N., A.N., M.K., and S.I. were engaged in the manufacture of the rice koji; and K.M. wrote the paper.

Funding: This research received no external funding. 
Acknowledgments: The study was supported by a grant from the Nagano Prefecture General Industrial Technology Center. Measurements of the PA and LPA contents in steamed rice and rice koji were performed by the Kansai Research Institute, Inc., Japan and the Chemicals Evaluation and Research Institute, Japan.

Conflicts of Interest: The authors declare no conflicts of interest.

\section{References}

1. Maeda, K.; Nakata, K.; Nakamura, A.; Kitagawa, M.; Ito, S. Improvement in skin conditions by consumption of traditional Japanese miso soup and its mechanism. J. Nutr. Food Sci. 2018, 8, 1. [CrossRef]

2. Kitamoto, K. Bunshi Kojikin Gaku; Revised Version; The Brewing Society of Japan: Tokyo, Japan, 2012. (In Japanese)

3. Iwano, K. Seisyu shuzou to kouso. J. Brew. Soc. Jpn. 1974, 74, 206-212. (In Japanese)

4. Ministry of Education, Culture, Sports, Science and Technology, Japan. Standard Tables of Food Composition in Japan (Seventh Revised Version). 2015. Available online: http:/ /www.mext.go.jp/en/policy/science_ technology/policy/title01/detail01/1374030.htm (accessed on 14 April 2018).

5. Ohnishi, K.; Yoshida, Y.; Toita, J.; Sekiguchi, J. Purification and characterization of a novel lipolytic enzyme from Aspergillus oryzae. J. Ferment. Bioeng. 1994, 78, 413-419. [CrossRef]

6. Watanabe, T.; Owari, K.; Hori, K.; Takahashi, K. Selection of koji mold strain for making functional miso as rich antimutagenic activity. Nippon Shokuhin Kagaku Kogaku Kaishi 2004, 51, 698-702. (In Japanese) [CrossRef]

7. Ohnishi, M.; Fujino, Y. Molecular species of free ceramides in Aspergillus oryzae. Agric. Biol. Chem. 1976, 40, 1419-1426. [CrossRef]

8. Hosoyama, H.; Oisawa, M.; Hamano, M. Bifidobacterium growth promoting substance in rice bran koji extract. Nippon Shokuhin Kogyo Gakkaishi 1991, 38, 940-944. [CrossRef]

9. Hamajima, H.; Matsunaga, H.; Fujikawa, A.; Sato, T.; Mitsutake, S.; Yanagita, T.; Nagao, K.; Nakayama, J.; Kitagaki, H. Japanese traditional dietary fungus koji Aspergillus oryzae functions as a prebiotic for Blautia coccoides through glycosylceramide: Japanese dietary fungus koji is a new prebiotic. Springerplus 2016, 5, 1321. [CrossRef] [PubMed]

10. Kawasumi, T.; Sato, M.; Tsuriya, Y.; Ueno, S. Antioxidant activity of a medicine based on Aspergillus oryzae NK koji measured by a modified t-butyl peroxyl radical scavenging assay. Biosci. Biotechnol. Biochem. 1999, 63, 581-584. [CrossRef] [PubMed]

11. Yamada, T.; Hiratake, J.; Aikawa, M.; Suizu, T.; Saito, Y.; Kawato, A.; Suginami, K.; Oda, J. Cysteine protease inhibitors produced by the industrial koji mold, Aspergillus oryzae O-1018. Biosci. Biotechnol. Biochem. 1998, 62, 907-914. [CrossRef] [PubMed]

12. Morimoto, H.; Gu, L.; Zeng, H.; Maeda, K. Amino carbonylation of epidermal basement membrane inhibits epidermal cell function and is suppressed by methylparaben. Cosmetics 2017, 4, 38. [CrossRef]

13. Feingold, K.R.; Elias, P.M. Role of lipids in the formation and maintenance of the cutaneous permeability barrier. Biochim. Biophys. Acta. 2014, 1841, 280-294. [CrossRef] [PubMed]

14. Groen, D.; Poole, D.S.; Gooris, G.S.; Bouwstra, J.A. Investigating the barrier function of skin lipid models with varying compositions. Eur. J. Pharm. Biopharm. 2011, 79, 334-342. [CrossRef] [PubMed]

15. Elias, P.M.; Menon, G.K. Structural and lipid biochemical correlates of the epidermal permeability barrier. Adv. Lipid Res. 1991, 24,1-26. [PubMed]

16. Norlén, L.; Nicander, I.; Lundh Rozell, B.; Ollmar, S.; Forslind, B. Inter- and intra- individual differences in human stratum corneum lipid content related to physical parameters of skin barrier function in vivo. J. Invest. Dermatol. 1999, 112, 72-77. [CrossRef] [PubMed]

17. Hamanaka, S.; Hara, M.; Nishio, H.; Otsuka, F.; Suzuki, A.; Uchida, Y. Human epidermal glucosylceramides are major precursors of stratum corneum ceramides. J. Invest. Dermatol. 2002, 119, 416-423. [CrossRef] [PubMed]

18. Van Smeden, J.; Hoppel, L.; van der Heijden, R.; Hankemeier, T.; Vreeken, R.J.; Bouwstra, J.A. LC/MS analysis of stratum corneum lipids: Ceramide profiling and discovery. J. Lipid Res. 2011, 52, 1211-1221. [CrossRef] [PubMed]

19. Holleran, W.M.; Takagi, Y.; Menon, G.K.; Jackson, S.M.; Lee, J.M.; Feingold, K.R.; Elias, P.M. Permeability barrier requirements regulate epidermal beta-glucocerebrosidase. J. Lipid Res. 1994, 35, 905-912. [PubMed] 
20. Hanley, K.; Jiang, Y.; Holleran, W.M.; Elias, P.M.; Williams, M.L.; Feingold, K.R. Glucosylceramide metabolism is regulated during normal and hormonally stimulated epidermal barrier development in the rat. J. Lipid Res. 1997, 38, 576-584. [PubMed]

21. Uchida, Y.; Hara, M.; Nishio, H.; Sidransky, E.; Inoue, S.; Otsuka, F.; Suzuki, A.; Elias, P.M.; Holleran, W.M.; Hamanaka, S. Epidermal sphingomyelins are precursors for selected stratum corneum ceramides. J. Lipid Res. 2000, 41, 2071-2082. [PubMed]

22. Jensen, J.M.; Fölster-Holst, R.; Baranowsky, A.; Schunck, M.; Winoto-Morbach, S.; Neumann, C.; Schütze, S.; Proksch, E. Impaired sphingomyelinase activity and epidermal differentiation in atopic dermatitis. J. Invest. Dermatol. 2004, 122, 1423-1431. [CrossRef] [PubMed]

23. Oliveira Mdos, S.; Feddern, V.; Kupski, L.; Cipolatti, E.P.; Badiale-Furlong, E.; de Souza-Soares, L.A. Changes in lipid, fatty acids and phospholipids composition of whole rice bran after solid-state fungal fermentation. Bioresour. Technol. 2011, 102, 8335-8338. [CrossRef] [PubMed]

24. Singh, A.; Baranwal, V.; Shankar, A.; Kanwar, P.; Ranjan, R.; Yadav, S.; Pandey, A.; Kapoor, S.; Pandey, G.K. Rice phospholipase A superfamily: Organization, phylogenetic and expression analysis during abiotic stresses and development. PLoS ONE 2012, 7, e30947. [CrossRef] [PubMed]

25. Lee, M.H. Phospholipase D of rice bran. I. Purification and characterization. Plant Sci. 1989, 59, $25-33$. [CrossRef]

26. Ueki, J.; Morioka, S.; Komari, T.; Kumashiro, T. Purification and characterization of phospholipase D (PLD) from rice (Oryza sativa L.) and cloning of cDNA for PLD from rice and maize (Zea mays L.). Plant Cell Physiol. 1995, 36, 903-914. [CrossRef] [PubMed]

27. Watanabe, I.; Koishi, R.; Yao, Y.; Tsuji, T.; Serizawa, N. Molecular cloning and expression of the gene encoding a phospholipase A1 from Aspergillus oryzae. Biosci. Biotechnol. Biochem. 1999, 63, 820-826. [CrossRef] [PubMed]

28. Shiba, Y.; Ono, C.; Fukui, F.; Watanabe, I.; Serizawa, N.; Gomi, K.; Yoshikawa, H. High-level secretory production of phospholipaseA1 by Saccharomyces cerevisiae and Aspergillus oryzae. Biosci. Biotechnol. Biochem. 2001, 65, 94-101.

29. Liu, L.; Waters, D.L.; Rose, T.J.; Bao, J.; King, G.J. Phospholipids in rice: significance in grain quality and health benefits: A review. Food Chem. 2013, 139, 1133-1145. [CrossRef] [PubMed]

30. Tong, C.; Liu, L.; Waters, D.L.; Rose, T.J.; Bao, J.; King, G.J. Genotypic variation in lysophospholipids of milled rice. J. Agric. Food Chem. 2014, 62, 9353-9361. [CrossRef] [PubMed]

31. AspGD. A. oryzae AO090005000433 Summary. The Board of Trustees, Leland Stanford Junior University. Available online: http:/ / www.aspergillusgenome.org/cgi-bin/locus.pl?locus=AO090005000433\#citations (accessed on 14 April 2018). 